\title{
REINFORCEMENT SKILL DALAM PEMBELAJARAN PAI (Studi Kasus di SMA Bukit Barisan Padang)
}

\author{
Misra \\ Dosen Fakultas Tarbiyah IAIN Imam Bonjol Padang \\ e-mail: misra@yahoo.com
}

\begin{abstract}
The purpose of the study is to describe positive contribution of Reinforcement Skill to make-up of productive behaviour and creativity of student and to investigate supplementary factor and his resistor. Result of research depict that theoretically learn have applied skill reinforcement in course of study but not yet optimal fully, precisely or as according to what expected. Special at study of PAI applying of skill reinforcement enough give positive contribution to creativity and improvement of productive behaviour of student, this matter see step by step can awaken ardour and spirit of learning active student, inovatif, effective, pleasant and creative.
\end{abstract}

\begin{abstract}
Abstrak: Tujuan yang ingin dicapai dalam penelitian ini adalah untuk mendeskripsikan penerapan Reinforcement Skill oleh guru dalam pembelajaran PAI di SMA Bukit Barisan Padang dan menjelaskan kontribusi terhadap peningkatan kreativitas dan tingkah laku produktif siswa serta mengetahui faktor pendukung dan penghambatnya. Hasil penelitian menggambarkan bahwa secara teori guru telah menerapkan reinforcement skill dalam proses pembelajaran tapi belum sepenuhnya optimal, tepat atau sesuai dengan apa yang diharapkan. Khusus pada pembelajaran PAI penerapan reinforcement skill cukup memberikan kontribusi positif terhadap kreativitas dan peningkatan tingkah laku produktif siswa, hal ini tampak secara bertahap mampu membangkitkan kegairahan dan semangat belajar siswa yang aktif, inovatif, efektif, kreatif dan menyenangkan.
\end{abstract}

Kata kunci: Reinforcement Skill, Pembelajaran, Pendidikan Agama Islam.

\section{PENDAHULUAN}

Keberadaan guru bagi suatu bangsa, terutama bangsa yang sedang membangun menempati posisi yang urgent. Guru termasuk salah satu komponen strategis yang menentukan gerak majunya kehidupan suatu bangsa. Profesi guru adalah posisi yang harus ditempati oleh mereka yang betul-betul mau mengabdikan dirinya sebagai tenaga pendidik yang bertugas untuk memanusiakan manusia semanusiawi mungkin dan mampu pula membukakan hati generasi demi generasi.

Sebagai seorang guru yang professional seyogyanya mampu pula mengajar secara professional dan berhasil mencapai tujuan pendidikan yang diharapkan serta dapat dipertanggungjawabkan secara didaktik dan metodik. Oleh karena itu guru harus mengetahui dan memahami serta dapat mengaplikasikan prinsip-prinsip tertentu dalam mengajar, yang kemudian disebut juga dengan asas didaktik yang telah ditentukan. adalah:

Adapun prinsip-prinsip mengajar itu

1. Asas perhatian: asas membangkitkan perhatian siswa.

2. Asas aktivitas: asas membangkitkan jasmani dan rohani siswa.

3. Asas apersepsi: asas mengakaitkan apa yang telah dikenal siswa.

4. Asas peragaan: asas memperagakan pengajaran.

5. Asas ulangan: asas mengadakan ulanganulangan yang teratur.

6. Asas korelasi: asas mengadakan hubungan pelajaran.

7. Asas konsentrasi: asas pemusatan pada pokok masalah

8. Asas individual: asas penyesuaian pada sifat dan bakat anak

9. Asas sosialisasi: asas menciptakan/ menyesuaikan pada lingkungan.

10. Asas evaluasi: asas mengadakan penilaian yang tepat dan teliti. (Tim Didaktik Metodik, 1993: 21). 
Selain dari 10 prinsip mengajar di atas, kegiatan pembelajaran akan berjalan lebih efektif dan efisien maka harus juga memiliki berbagai keterampilan dasar mengajar bagi guru antara lain adalah :

1. Keterampilan bertanya (questioning skill).

2. Keterampilan memberi penguatan (reinforcement skill).

3. Keterampilan mengadakan variasi (variation skill).

4. Keterampilan menjelaskan (explaining skill).

5. Keterampilan membuka dan menutup Pelajaran.

6. Keterampilan membimbing diskusi.

7. Keterampilan mengelola kelas.

8. Keterampilan mengajar kelompok kecil. (Moh. Uzer Usman, 2008: 74)

Keterampilan dasar mengajar bagi guru diperlukan agar guru dapat melaksanakan perannya dalam pengelolaan proses pembelajaran, sehingga pembelajaran dapat berjalan secara efektif dan efisien. Di samping itu, keterampilan dasar mengajar merupakan syarat mutlak agar guru bisa mengimplementasikannya dalam berbagai kegiatan pembelajaran, salah satunya adalah keterampilan memberi penguatan (reinforcement skill).

Keterampilan memberi penguatan (reinforcement skill) merupakan respons terhadap suatu tingkah laku positif yang dapat meningkatkan kemungkinan berulangnya kembali tingkah laku tersebut. Pengertian lain dari reinforcement skill dapat juga diartikan sebagai suatu penghargaan, persetujuan atau dukungan yang berupa ungkapan kata-kata yang diberikan oleh guru kepada siswa terhadap hal positif yang dilakukan siswa. Misalnya kata-kata "Bagus sekali, pendapat yang kamu kemukakan sangat tepat" atau "Wah, pendapat kamu sangat beralasan sekali" atau "Tepat sekali, alasan yang kamu kemukakan cukup argumentatif. Ungkapan pujian atau penghargaan seperti ini diharapkan siswa dapat termotivasi untuk mengulang kembali jawaban yang tepat di lain kesempatan. (Gilarso Suseno,1986: 72)

Pada umumnya penghargaan dapat memberi pengaruh positif terhadap kehidupan manusia, mendorong dan memperbaiki tingkah laku seseorang serta meningkatkan usahanya.
Keterampilan memberi penguatan (reinforcement skill) dalam bentuk kata-kata seperti pujian atau penghargaan tersebut, merupakan bagian dari modifikasi tingkah laku guru terhadap tingkah laku siswa atas perbuatannya. Hal ini dilakukan sebagai salah satu cara untuk meningkatkan perhatian siswa terhadap pelajaran, merangsang dan meningkatkan motivasi serta semangat belajar dalam membina tingkah laku produktif siswa. Bukan hal yang aneh apabila seseorang ingin menjadi yang terbaik dan mendapat pujian tentu saja dalam batas-batas yang wajar. Maka dalam kegiatan pembelajaran reinforcement skill mempunyai peranan yang sangat urgent, tidak hanya dalam bentuk katakata melainkan bisa juga dalam bentuk bahasa isyarat. Misalnya seperti senyuman, anggukan kepala, mengernyitkan dahi, mengangkat pundak bahkan denga sentuhan sekalipun.

Fokus permasalahan dalam penelitian ini adalah bagaimana penerapan reinforcement skill oleh guru dalam pembelajaran PAI di SMA Bukit Barisan Padang, dan sejauhmana kontribusi reinforcement skill terhadap kreatifitas dan peningkatan tingkah laku produktif siswa serta faktor pendukung dan penghambatnya.

Tulisan khusus yang mengkaji tentang permasalahan Reinforcement Skill, dalam pembahasan penelitian hingga sekarang belum ada penulis temukan. Akan tetapi ada beberapa pembahasan mengenai beberapa keterampilan mengajar yang ditulis secara parsial atau sebahagiannya, baik dalam bentuk buku maupun penelitian yang menyangkut dengan keterampilan mengajar guru.

Mazidah misalnya, dalam penelitiannya tentang implementasi keterampilan pengelolaan kelas dalam pembelajaran PAI di SMPN 18 Semarang. Menjelaskan bahwa pengelolaan kelas merupakan keterampilan guru untuk menciptakan dan memelihara kondisi belajar yang optimal dan mengembalikannya bila terjadi gangguan dalam kegiatan. Ia juga mengungkapkan bahwa pengelolaan kelas yang baik dalam pembelajaran tidak cukup hanya menyangkut pengelolaan kelas dan pengaturan siswa di kelas saja, tapi harus disertai juga dengan pengaturan ruangan, sarana dan prasarana serta penyampaian materi ajar yang bervariasi agar siswa tidak 
bosan sehingga dapat menyerap materi yang disampaikan oleh guru dengan baik.

Penulis melihat bahwa penelitian tersebut lebih menfokuskan kepada kemampuan guru dalam mengelola kelas, menata ruang belajar, sarana dan prasarana belajar dan penyampaian materi ajar yang variatif. Penulis belum lagi menemukan bagaimana upaya dan langkah-langkah pelaksanaannya di kelas. Begitu juga halnya dengan apa yang diungkapkan oleh Nurgiati, dalam penelitiannya tentang Implementasi Pendekatan Keterampilan Proses dalam Pembelajaran PAI di SD Islam al-Azhar 25 Semarang. Ia mengungkapkan bahwa keterampilan proses harus diwujudkan dengan menggabungkan keterampilan, mengamati, menggolongkan, menafsirkan, menerapkan, merencanakan penelitian dan mengkomunikasikan sebagai aktivitas belajar siswa agar siswa mengalami sendiri proses mendapatkan pengetahuan. Nurgiati memapar-kan hasil penelitiannya masih bersifat umum dan belum nampak seperti apa bentuk penggabungan keterampilan proses itu menjadi suatu aktivitas belajar sehingga siswa mengalami sendiri proses mendapatkan pengetahuannya. Lebih dari itu belum dijelaskan juga sejauh mana penggabungan keterampilan proses itu dapat memberikan kontribusi positif terhadap aktivitas belajar siswa.

Lain halnya dengan penjelasan Karyadi, ia menyanggah apa yang diungkapkan oleh Nurgiati tersebut, menurutnya keterampilan proses dalam penerapannya terkadang mempunyai kelebihan dan kelemahan. Adapun kelebihannya adalah guru akan lebih aktif dan kreatif dalam setiap pembelajaran serta akan tertantang untuk menggali kemampuannya agar punya motivasi yang tinggi, materi ajar yang relevan akan dapat menarik minat siswa untuk lebih aktif dan kreatif, suasana yang kondusif akan menimbulkan kegairahan dan menyenangkan bahkan akan terjalin interaksi dua arah antara guru dengan siswa dan metode yang variatif pasti tidak akan membosankan atau menimbulkan kejenuhan siswa dalam belajar. Adapun kelemahannya adalah tidak semua kemampuan keterampilan pendekatan proses itu dapat dipraktekkan dalam pembelajaran PAI, karena kompetensi professional guru yang tinggi sangat dituntut dalam menguasai media pembelajaran, membutuhkan alat-alat dan sarana parsarana pengajaran yang lengkap, biaya yang dibutuhkan lebih banyak, waktu yang tersedia sangat terbatas dan tingkat kecerdasan siswa yang beragam. Demikian dijelaskan dalam penelitiannya tentang "Studi Kritis terhadap Implementasi Pendekatan Keterampilan Proses dalam Pembelajaran PAI di SMAN 13 Semarang.

Menurut analisis penulis, dari kedua penelitian di atas sedikit agak bertolak belakang, Nurgiati menyebutkan bahwa keterampilan proses dapat terwujud dengan adanya penggabungan beberapa keterampilan seperti mengamati, menggolongkan, menafsirkan, menerapkan, merencanakan penelitian dan mengkomunikasikan sebagai aktivitas belajar siswa. Sedangkan Karyadi menyebutkan tidak semua keterampilan itu dapat dipraktekkan dalam pembelajaran PAI, sebab dalam kenyataannya kompetensi guru, media atau alat serta sarana dan prasarana belajar sangat terbatas demikian juga halnya waktu dan tingkat kemampuan siswa yang beragam, sangat tidak memungkinkan diterapkan dalam setiap pembelajaran.

Sementara itu, Santi Anggraini juga menjelaskan dalam penelitiannya tentang Implementasi Keterampilan Membuka dan Menutup Pelajaran dalam Pembelajaran PAI di MTs NU 15 Jurangagung Kecamatan Plantungan Kabupaten Kendal. Penelitian ini lebih menitikberatkan terhadap tujuan dari keterampilan membuka dan menutup pelajaran. Menurutnya keterampilan membuka pelajaran bertujan untuk memusatkan perhatian siswa terhadap pelajaran yang akan diajarkan dengan cara menarik perhatian siswa, seperti gaya guru yang cukup variatif, media pembelajaran yang cukup, variasi dalam pola interaksi yang dilakukan dengan sikap guru yang ramah, memberi acuan dilakukan dengan mengingatkan kembali, menyangkutkan judul yang dipelajari dan menerangkan tujuan pembelajaran, mengkaitkan pelajaran dengan permasalahan sehari-hari dan juga pelajaran yang lain.

Sedangkan dalam menutup pelajaran, setiap guru melakukannya dengan meninjau ulang kembali materi yang baru diajarkan dengan cara merangkum pelajaran dan 
memberikan evaluasi baik yang dilakukan mengajukan beberapa pertanyaan kepada siswa maupun dengan cara memberikan tugas di rumah.

Penelitian ini lebih menfokuskan terhadap serangkaian kegiatan yang dilakukan guru mulai dari kegiatan membuka pelajaran hingga kegiatan menutup pelajaran. Sehingga siswa dapat mengikuti proses pembelajaran dengan baik mulai dari awal sampai berakhirnya jam pelajaran sesuai dengan waktu yang tersedia.

Menelisik dari beberapa penelitian di atas yang mengupas berbagai macam keterampilan dasar mengajar guru. Penulis belum menemukan adanya penelitian dan pengkajian yang difokuskan terhadap Reinforcement Skill dalam pembelajaran PAI, apalagi penelitiannya di SMA Bukit Barisan Padang. Jika Mazidah lebih mengarahkan penelitiannya pada keterampilan pengelolaan kelas, sementara Nurgiati dan Karyadi terfokus pada pendekatan keterampilan proses dan Santi Anggraini memilih terhadap keterampilan membuka dan menutup pelajaran dalam pembelajaran PAI. Maka spesifikasi penelitian ini akan mendeskripsikan bagaimana upaya penerapan Reinforcement Skill, kontribusinya dan juga faktor pendukung dan penghambatnya dalam Pembelajaran PAI di SMA Bukit Barisan Padang. Untuk itu penulis tertarik mengadakan suatu penelitian yang lebih mendalam lagi dengan judul "Reinforcement Skill dalam pembelajaran PAI (Studi Kasus di SMA Bukit Barisan Padang)".

Tujuan yang ingin dicapai dalam penelitian ini adalah untuk mendeskripsikan penerapan Reinforcement Skill oleh guru dalam pembelajaran PAI di SMA Bukit Barisan Padang dan menjelaskan kontribusinya terhadap peningkatan kreativitas dan tingkah laku produktif siswa serta mengetahui faktor pendukung dan penghambatnya.

\section{METODE}

1. Teknik Pengumpulan Data

a. Pengamatan (observation), yaitu pengamatan secara langsung (direct observation) terhadap proses belajar mengajar di kelas. Alat yang penulis gunakan dalam mengadakan pengamatan ini yaitu: Pertama, daftar cek (checklist). Daftar cek ini penulis maksudkan agar semua gejala yang akan muncul pada saat berlangsungnya kegiatan pembelajaran di kelas dapat didaftar secermat mungkin sesuai dengan masalah yang diteliti, juga disediakan kolom cek yang digunakan selama mengadakan pengamatan. Berdasarkan butir (item) yang ada pada daftar cek, jika suatu gejala muncul dibubuhkan tanda cek (V) pada kolom yang tersedia. Hal ini penulis anggap memungkinkan dapat dengan mudah mengamati seluruh gejala yang muncul sesuai dengan data yang dibutuhkan. Kedua, daftar isian. Daftar isian ini memuat daftar butir (item) yang diamati dan kolom tentang keadaan atau gejala tentang item-item tersebut. Observasi seperti ini dipakai untuk mengamati bagaimana penerapan reinforcement skill oleh guru yang berlangsung di kelas secara umum. Seperti teknik guru menerapan reinforcement, teknik menumbuhkan motivasi siswa dalam belajar, teknik membangun komunikasi interaktif edukatif dan teknik memilih metode mengajar yang tepat. Kelas yang penulis amati itu terdiri dari kelas X: (1 lokal), kelas XI: (2 lokal) dan kelas XII: (2 lokal). Namun yang diobservasi cukup 3 lokal saja dengan ketentuan tiap-tiap kelasnya 1 lokal. Hai ini penulis lakukan dengan alasan bahwa guru yang mengajar mata pelajaran PAI di kelas XI IPA dan IPS dianggap sama cara mengajarnya begitu juga halnya dengan kelas XII IPA dan IPS. Maka untuk masingmasing kelas yang diobservasi cukup 1 lokal saja, dalam hal ini penulis sendiri turut membantu dan terlibat secara langsung dalam kegiatan pembelajaran PAI di kelas yang bersangkutan.

b. Wawancara (interview), wawancara ini penulis maksudkan sebagai alat tukar menukar informasi atau alat pengumpul data dengan terlebih dahulu membuat daftar pertanyaan yang akan dijadikan pedoman dalam pelaksanaannya seperti membuat layout pedoman wawancara dan kemudian memilih pertanyaan yang relevan. Pada awalnya dipakai wawancara tak berstruktur karena pertanyaan-pertanyaan belum spesifik. Kemudian dilanjutkan dengan wawancara berstruktur dengan pertanyaan- 
pertanyaan yang spesifik yang disusun berdasarkan apa yang telah disampaikan responden. Wawancara ini dilakukan pertama kali kepada guru sebagai orang yang terlibat langsung dalam menerapkan reinforcement kepada siswa dalam kegiatan pembelajaran di kelas dan yang kedua adalah siswa sebagai orang yang merasakan dampak atau manfaat dari reinforcement yang diterapkan oleh guru. Kedua sumber data (guru dan siswa) tersebut penulis interview guna memperoleh informasi tentang bagaimana penerapan reinforcement skill di SMA Bukit Barisan Padang. Terutama sekali pada mata pelajaran PAI yang diterapkan oleh guru PAI itu sendiri yang meliputi teknik menumbuhkan motivasi siswa dalam belajar, teknik membangun komunikasi interaktif edukatif dan juga teknik memilih metode yang tepat dalam mengajar. Beberapa pertanyaan itu disusun menurut jenis-jenis pertanyaan yang sesuai dengan permasalahan di mana semua subyek mempunyai kesempatan yang sama untuk menjawab pertanyaan dengan mengambil sejumlah sampel yang representatif atau dibuat wawancara berstruktur. Namun untuk memperoleh gambaran yang lebih luas terhadap responden terkadang tak berstruktur. Adapun pokok permasalahan dalam wawancara adalah masalah penerapan reinforcement, kontribusinya dalam meningkatkan kreatifitas dan tingkah laku produktif siswa dan juga hal-hal yang menjadi pendukung serta kendala-kendala dalam penerapannya.

\section{Teknik Analisa Data}

Untuk menganalisa data yang bersifat kualitatif, akan dibuat kategorisasi berdasarkan masalah dan tujuan agar data tersebut mempunyai makna. Data kualitatif digambarkan dengan kata-kata atau kalimat untuk memperoleh kesimpulan.(Suharsimi Arikunto, 1991: 245).

Berdasarkan tujuan penelitian yang hendak dicapai, maka teknik analisis data dalam penelitian ini adalah deskriptif analitik, yaitu mendiskripsikan dan menginterpretasikan secara faktual dan akurat mengenai fakta-fakta tentang penerapan reinforcement skill dalam pembelajaran PAI di SMA Bukit Barisan Padang yang meliputi, bagaimana strategi pelaksanaannya dalam pembelajaran, sejauh mana kontribusinya terhadap kreatifitas dan peningkatan tingkah laku produktif siswa dan apa pula faktor pendukung dan penghambat dalam penerapannya.

\section{HASIL DAN PEMBAHASAN}

A. Penerapan Reinforcement Skill dalam PAI di SMA Bukit Barisan Padang

1. Tahap Persiapan (Pre Conditions)

Persiapan atau perencanaan adalah pemikiran sebelum pelaksanaan tugas. Persiapan mengajar adalah pemikiran tentang penerapan prinsip-prinsip mengajar dalam pelaksanaan mengajar baik di kelas maupun di luar kelas. (Team Didaktik Metodik, 1993:125)

Selanjutnya untuk mengetahui bagaimana penerapan reinforcement skill dalam pembelajaran PAI di SMA Bukit barisan Padang. Berikut ini akan dijelaskan tahapan-tahapan atau persiapan-persiapan yang dilakukan oleh guru dalam menerapkan reinforcement dalam pembelajaran PAI adalah sebagai berikut:

1. Persiapan dalam Penguatan Verbal

Dalam menerapkan penguatan verbal misalnya, ketika guru mengajukan sebuah pertanyaan kemudian siswa menjawab dengan tepat, maka guru memuji siswa tersebut dengan mengatakan, seperti kata-kata: "Bagus", “Tepat sekali, "Wah, hebat kamu", dan lain sebagainya. Demikian juga ketika jawaban siswa kurang tepat atau kurang sempurna, guru berkata: "Hampir tepat", atau "Seratus kurang lima puluh", dan lain-lain. Guru dapat melakukannya dengan spontanitas tanpa direncanakan sebelumnya atau tanpa disiapkan secara totalitas. Menurut salah seorang guru Agama (Darwin) ia mengatakan bahwa:

"Penerapan penguatan verbal ini diterapkan guru berdasarkan kebiasaan guru di dalam kelas yang memang sering melakukannya saat-saat kegitan pembelajaran berlangsung. Hal ini diupayakan guru untuk menerapkannya dengan tujuan untuk memberikan ganjaran kepada siswa sehingga siswa akan berbesar hati dan dapat meningkatkan 
partisipasinya dalam setiap kegiatan pembelajaran".

(Wawancara, 25 Maret 2009).

Penulis melihat memang ada beberapa guru yang menerapkan reinforcement dalam bentuk penguatan verbal ini pada beberapa kelas pada saat berlansungnya pembelajaran. Tidak hanya pada bidang studi PAI, melainkan juga pada mata pelajaran yang lain terkesan bahwa penguatan verbal dapat memotivasi para siswa untuk terlibat berpartisipasi aktif dan kreatif dalam proses pembelajaran.(Observasi, 25 Maret 2009)

Berdasarkan hasil wawancara dan observasi langsung tersebut maka persiapan guru dalam menerapkan reinforcement dalam pembelajaran, terutama PAI tidak diterapkan secara terstruktur atau secara terencana dan tersusun rapi sebelumnya melainkan kalimat pujian atau penghargaan itu muncul dengan sendirinya sesuai kebiasaan dan pengalaman guru dalam setiap mengajar.

\section{Persiapan dalam Penguatan} Nonverbal

Adapun dalam penguatan nonverbal, seperti anggukan kepala tanda setuju, gelengan kepala tanda tidak setuju, mengernyitkan dahi, mengangkat pundak, senyuman, sorot mata yang sejuk dan bersahabat atau tajam memandang dan lain sebagainya.

"Itupun dilakukan guru secara spontanitas alias tidak direncanakan sebelumnya karena guru berfungsi di samping sebagai mediator dalam pembelajaran juga sebagai motivator bagimana siswa dapat menyenangi materi yang disajikan kepadanya. Sehingga dengan adanya ransangan seperti itu akan dapat menimbulkan gairah belajar yang aktif dan kreatif bagi setiap siswa. Lebih dari itu akan dapat meningkatkan atau menumbuhkan kreatifitas dan juga membina produktivitas siswa dalam belajar".

\begin{tabular}{rccr} 
Demikian & \multicolumn{2}{r}{ diungkapkan oleh } & salah \\
seorang guru & (Rini Oktavia) dalam
\end{tabular}

wawancaranya dengan penulis. (Wawancara, 25 Maret 2009)

Memang penulis setuju dengan apa yang diungkapkan oleh guru tersebut bahwa penguatan yang diterapkan dengan bahasa isyarat atau bahasa tubuh sekalipun akan dapat memberikan respon positif terhadap siswa dalam kegiatan pembelajaran. Penulis juga menyaksikan bahwa anggukan guru terhadap jawaban siswa yang tepat, dapat memberikan motivasi dan reaksi positif terhadap siswa yang bersangkutan. Sebaliknya, gelengan kepala dan kerut kening guru terhadap jawaban siswa yang tidak tepat sekalipun, juga dapat meransang siswa untuk lebih hati-hati dalam memberikan respon.(Observasi, 25 Maret 2009)

Berdasarkan hasil wawancara dan observasi tersebut dapat disimpulkan bahwa penerapan reinforcement dalam bentuk penguatan nonverbal, tidak ada perbedaan yang mendasar dengan penerapan verbal oleh guru dalam kegiatan pembelajaran. Penulis melihat hal semacam itu sudah sering diterapkan guru dalam setiap kali pembelajaran, akan tetapi guru tidak mengetahui kalau keterampilan mengajar seperti itu termasuk jenis reinforcement dalam bentuk verbal dan nonverbal.

\section{Tahap Pelaksanaan (operating procedures)}

Setelah selesai segala persiapan maka guru telah siap untuk melaksanakan rencananya dan dapat mengembangkan keterampilan yang dimilikinya dalam pembelajaran. Dalam pembelajaran guru memulainya dengan cara mengadakan pretest untuk mengetahun kemampuan dan kesiapan siswa dalam menerima pelajaran agar dapat mempermudah guru dalam menentukan gaya mengajarnya. Pada SMA Bukit Barisan Padang, penerapan reinforcement dalam pembelajaran PAI diterapkan dengan menggunakan jenis penguatan verbal dan nonverbal.

Mengenai pelaksanaan keterampilan penguatan oleh guru dalam proses belajar mengajar di SMA Bukit Barisan Padang, berdasarkan observasi yang penulis lakukan dapat dilihat sebagai berikut : 
Tabel. 1

Kemampuan Guru Melaksanakan Keterampilan Penguatan

\begin{tabular}{|c|c|c|c|c|c|}
\hline \multirow{2}{*}{ No } & \multirow{2}{*}{ Aspek yang dinilai } & \multicolumn{4}{|c|}{ Kode Penilaian } \\
\hline & & $\mathrm{A}$ & $\mathrm{B}$ & $\mathrm{C}$ & $\mathrm{D}$ \\
\hline 1. & $\begin{array}{l}\text { Kemampuan guru dalam } \\
\text { bertanya dan memberikan } \\
\text { penguatan terhadap setiap } \\
\text { jawaban yang diberikan } \\
\text { siswa }\end{array}$ & & $\sqrt{ }$ & & \\
\hline 2. & $\begin{array}{l}\text { Kemampuan guru dalam } \\
\text { menerapkan berbagai } \\
\text { keterampilan mengajar }\end{array}$ & & & $\sqrt{ }$ & \\
\hline
\end{tabular}

Keterangan Kode Penilaian:

$\begin{array}{lll}\text { A } & \text { : Baik } & \sqrt{ } \\ \text { B } & \text { : Sedang } & \sqrt{ } \\ \text { C } & \text { : Cukup } & \sqrt{ } \\ \text { D } & \text { : Kurang } & \sqrt{ }\end{array}$

Berdasarkan tabel di atas dapat diperoleh gambaran bahwa kemampuan guru-guru bertanya dan memberikan respon positif terhadap setiap jawaban yang diberikan siswa (penguatan) tergolong baik, hal ini penulis lihat sebagaimana dijelaskan dalam sub pembahasan terdahulu bahwasannya guru dalam menerapkan keterampilan bertanya sudah cukup baik karena pertanyaan yang diberikan adil untuk semua siswa sehingga siswa mempunyai kesempatan yang sama untuk menjawab. Dari hasil jawaban siswa guru akan langsung merespon baik secara verbal maupun non verbal. Dalam wawancara penulis dengan wakil kepala sekolah (Merita) mengenai penerapan keterampilan penguatan di SMA Bukit Barisan Padang dikatakan:

"Pada dasarnya setiap siswa harus diberlakukan sama dan sangat mengharapkan pujian, dan SMA Bukit Barisan Padang yang merupakan sebuah SMA yang berlabelkan Islam, pendekatan agamais melalui keterampilan penguatan sangat ditekankan, walau terkadang guru-guru sendiri bingung dengan defenisi penguatan, akan tetapi secara praktik setiap guru pasti sudah menetapkannya."(Wawancara, 25 April 2009).

Walaupun secara teori apa yang disampaikan salah seorang guru itu benar akan tetapi realitas di lapangan menurut penulis masih ada guru yang selalu memuji setiap jawaban yang diberikan siswa terlepas apakah itu betul ataupun salah, sebaliknya penulis juga melihat ada di antara guru yang kurang respon terhadap jawaban dari pertanyaan yang diberikannya sehingga suasana kelas penulis lihat kurang harmonis.

Mengenai kemampuan guru dalam menerapkan berbagai keterampilan penguatan dapat dilihat pada tabel berikut :

\section{Tabel. 2}

Kemampuan Guru Melaksanakan Berbagai Keterampilan Penguatan

(Jumlah guru 9 orang)

\begin{tabular}{|c|c|c|c|}
\hline No & Hal yang diamati & $\begin{array}{l}\text { Yang } \\
\text { mengguna } \\
\text { kan }\end{array}$ & $\begin{array}{l}\text { Tidak } \\
\text { mengguna } \\
\text { kan }\end{array}$ \\
\hline 1. & Penguatan verbal & 9 & - \\
\hline 2. & $\begin{array}{l}\text { Penguatan } \\
\text { mimik dan gerupa } \\
\text { badan }\end{array}$ & 7 & 2 \\
\hline 3. & $\begin{array}{l}\text { Penguatan dengan } \\
\text { sentuhan }\end{array}$ & 2 & 7 \\
\hline 4. & $\begin{array}{lr}\begin{array}{l}\text { Penguatan } \\
\text { kegiatan } \\
\text { menyenangkan }\end{array} & \text { yang } \\
\end{array}$ & 8 & 1 \\
\hline 5. & $\begin{array}{l}\text { Penguatan berupa } \\
\text { simbol atau benda }\end{array}$ & 1 & 8 \\
\hline 6. & $\begin{array}{l}\text { Penguatan dengan cara } \\
\text { mendekati }\end{array}$ & 5 & 4 \\
\hline
\end{tabular}

Tabel di atas dapat diperoleh gambaran tentang kemampuan guru dalam menerapkan berbagai keterampilan penguatan sebagai berikut:

Pertama, kemampuan guru dalam menerapkan keterampilan penguatan secara verbal dapat dilaksanakan oleh semua guru apakah itu penguatan dalam bentuk kata-kata ataupun penguatan dalam bentuk kalimat, akan tetapi meski telah dilaksanakan oleh semua guru dalam pelaksanaannya guru-guru masih terpaku dengan penggunaan kata bagus. Selanjutnya penguatan berupa mimik dan gerakan badan dilaksanakan oleh 7 orang guru baik dengan cara mengangguk, tersenyum, menatap, maupun dengan mengacungkan jempol, bahkan ada beberapa orang guru yang mengkombinasikannya dengan penguatan verbal yakni mengacungkan jempol sambil mengatakan bagus. Kedua, penguatan dengan sentuhan hanya dilaksanaka oleh dua orang guru dan setelah penulis amati serta menganalisa analisa dari biodata guru tersebut, mereka dapat dikategorikan guru yang sudah berumur, 
sehingga dalam melaksanakan penguatan sentuhan mereka tidak canggung lagi. Dalam hal ini penulis juga mewawancarai salah seorang guru (Desardin) ia mengatakan:

"Dalam memuji (memberi penguatan pada siswa) melalui sentuhan memang agak sulit diterapkan apalagi kepada siswa karena bisa menimbulkan interpretasi yang kurang baik dari siswi lain.”(Wawancara, 25 April 2009).

Menurut pengamatan penulis untuk penguatan sentuhan ini sebagaimana yang dikatakan oleh Moh. Uzer Usman bahwa penguatan sentuhan ini harus digunakan secara seksama agar sesuai dengan usia, jenis kelamin dan latar belakang budaya setempat. Ketiga, penguatan dengan kegiatan yang menyenangkan ada 8 orang guru yang melaksanakannya, hal ini diterapkan oleh guru misalnya dengan mengizinkan pulang/istirahat bagi siswa yang cepat mengerjakan tugas (dengan betul) atau memberikan tugas tambahan kepada siswa. Keempat, penguatan dengan simbol hanya satu orang yang menerapkannya karena setelah penulis bertanya kepada guru yang lain mereka rata-rata mengatakan kalau siswa sudah terbiasa diberikan benda untuk menghargai kerja atau jawaban yang diberikannya, bisa mematikan semangat para siswa yang pada awalnya untuk menuntut ilmu agar sukses menjadi supaya mendapat hadiah/benda tertentu dari guru. Kelima, sedangkan penguatan dengan cara mendekati dilaksanakan oleh 5 orang guru dengan berjalan menghampiri siswa atau berdiri di samping siswa, sementara 4 guru lain penulis melihat hanya terfokus duduk atau berdiri di depan kelas dan tidak melaksanakan berbagai keterampilan mengajar dalam proses pembelajaran di kelas. (Observasi, 25 Maret 2009)

\section{ANALISIS DAN PEMBAHASAN}

Pada setiap kegiatan pembelajaran berlangsung, guru dituntut agar mampu menyajikan pengajaran dengan baik dan dapat menciptakan kondisi pembelajaran yang efektif, karena pada hakekatnya pembelajaran itu merupakan upaya guru bagaimana dapat membelajarkan siswa untuk dapat mencapai tujuan yang telah ditetapkan, sehingga guru bertanggungjawab atas keberhasilan belajar siswa dalam interaksi edukatif.

Untuk mencapai tujuan pembelajaran yang telah ditetapkan, maka pembelajaran itu harus dapat dilaksanakan secara maksimal dan menuntut kemampuan guru untuk memiliki kreatifitas mengajar yang tinggi. Salah satunya guru dituntut agar mampu menerapkan berbagai keterampilan mengajar dengan tujuan agar siswa tidak merasa jenuh atau bosan dalam mengikuti kegiatan pembelajaran yang dapat menghambat tercapainya tujuan pembelajaran yang diharapkan.

Adanya keterampilan mengajar sangat memungkinkan siswa dapat lebih bersemangat untuk belajar dan dapat memahami proses pembelajaran yang lebih sistematis, efektif dan efisien.

Selanjutnya dalam penerapan reinforcement skill di SMA Bukit Barisan Padang, para guru telah mencoba melaksanakannya dalam kegiatan pembelajaran, hal ini dapat dilihat mulai dari tahap persiapan hingga pelaksanaannya:

1. Persiapan

Persiapan atau perencanaan merupakan penyusunan sesuatu yang akan dilakukan untuk mencapai tujuan yang telah ditentukan. Yang penting adalah perencanaan yang dibuat harus dapat dilaksanakan dengan mudah dan tepat sasaran. Mempersiapkan pelajaran adalah penting untuk kesuksesan guru, dalam mengajar setiap guru harus mempersiapkan bahan atau materi yang akan diajarkan dengan sebaik mungkin.

Maksud dengan persiapan di sini bukan berarti bahwa sebelum mengajar guru harus belajar atau mempelajari dulu bahan apa yang akan diajarkan, karena pada dasarnya guru mesti sudah menguasai bahan tersebut sebelumnya. Namun seorang guru perlu memperkaya pengetahuan dan wawasannya dengan selalu rajin membaca, dan mempersiapkan diri sebelum mengajar akan membuat guru lebih siap untuk mengajar.

Menurut Djamaluddin Darwis, bahwa membuat perencanaan ibarat membuat design bangunan yang terdiri dari unsur-unsur dan dilaksanakan secara bertahap. Menurutnya membuat perencanaan perlu memperhatikan 
komponen-komponen atau unsur-unsur pengajaran yaitu :

a. Tujuan, yang berfungsi menentukan arah kegiatan pembelajaran, kemana pembelajaran akan diarahkan

b. Bahan, yang berfungsi memberi isi dan makna terhadap tujuan pembelajaran

c. Metode dan alat pengajaran, yang berfungsi sebagai jembatan atau cara untuk mencapai tujuan

d. Evaluasi, yang berfungsi untuk menentukan keberhasilan pembelajaran dan memberikan feedback guna penyempurnaan dan pengembangan pembelajaran yang lebih baik. ((Djamaluddin Darwis, 1990: 226))

Hasil penelitian diketahui bahwa persiapan-persiapan yang dilakukan guru PAI di SMA Bukit Barisan Padang dalam melaksanakan reinforcement skill adalah:

\section{1). Persiapan dalam bentuk penguatan verbal}

Sebagaimana yang diketahui bahwa pujian dan dorongan yang diucapkan oleh guru untuk respon atas tingkah laku siswa yang positif adalah penguatan verbal. tepat dan lain sebagainya. Dapat juga berupa kalimat: misalnya hasil pekerjaanmu baik sekali atau sesuai benar tugas yang kamu kerjakan.

Akan halnya di SMA Bukit Barisan Padang, penguatan semacam ini pada dasarnya sebelum guru menerapkannya dalam pembelajaran di kelas, terlebih dahulu guru mempersipakan diri untuk tampil maksimal dan prima untuk mengajar. Hal ini terlihat bagaimana guru sangat berhati hati memilih pola pemberian penguatan terhadap seorang siswa sebagai individu atau sebagai anggota kelompok kelas. Karena pola dan frekuensi pemberian penguatan akan berhubungan dengan kebutuhan individu, kepentingan, tingkah laku dan kemampuan siswa. mengatakan; Marini (Salah seorang guru)

"Dalam persipan penerapan keterampilan seperti reinforcement ini guru tidak memiliki catatan atau perencanaan sebelumnya. Karena penguatan itu diberikan menurut respon yang muncul dari siswa saja dan untuk mendapatkan respon yang baik dari siswa itu sangat tergantung dengan bagaimana taktik atau strategi guru pada awal pembelajaran di mulai mampukan guru menumbuhkan semanagat atau membangun sitimulus untuk memancing konsentarsi siswa dalam belajar. Dengan hal semacam itu maka dengan sendirinya respon itu akan muncul secara spontanitas, kehangatan dan keantusisan siswapun akan lebih tanpak bergairah. (Wawancara: tanggal, 25 April 2009).

\section{2). Persiapan dalam bentuk penguatan nonverbal}

Adapun persipan guru dalam bentuk penguatan ninverbal penulis melihat tidak jauh berbeda dengan persipan dalam bentuk verbal karena pada dasarnya masing-masing guru merasa mampu memberikan bentuk-bentuk penguatan itu dalam pembelajaran. Para guru tidak terlalu memfokuskan diri dengan berbagai rencana dan program yang terfokus karena menurut beberapa orang guru penguatan itu muncul terkadang secara spontanitas tanpa direncanakan sebelumnya.

Hal ini sebagaimana yang diungkapkan oleh seorang guru (Desardin) menurut beliau;

"kita para guru akan dapat memberikan penguatan verbal dan nonverbal itu apabila ada respon positif dari siswa terhadap stimulus yang diberikan guru. Respon itupun akan muncul tergantung sejauhmana guru mampu membangun stimulus terhadap siswa sehingga dari rangsangan itu diharapkan dapat memberikan respon positif bagi setiap siswa agar memudahkan bagi guru untuk memberikan penguatan nantinya". (Wawancara; tanggal, 25 April 2009).

Pada waktu yang bersamaan Nela, (seorang guru) juga mengatakan:

"Untuk memberikan penguatan bentuk nonverbal seperti mimik dan gerakan badan, cara mendekati, sentuhan, kegiatan yang menyenangkan, dengan syimbol atau benda dan penguatan tidak penuh. Semua itu diterapkan oleh guru tanpa direncanakan sebelumnya karena penghargaan semacam itu sifatnya reflexi atau spontanitas adanya, seiring dengan 
adanya respon dari siswa terhadap kepiawaian guru menciptakan pembelajaran yang aktif dan kreatif melalui keterampilan mengajar yang dimilikinya itu". (Wawancara; tanggal, 25 April 2009)

Berdasarkan dari penjelasan dan ungkapan beberapa orang guru tersebut, penulis dapat menyimpulkan bahwa persipan guru dalam menerapkan beberapa keterampilan mengajar terutama reinforcement skill mereka (para guru) tidak mempersiapkan secara terencana atau tersusun sebagaimana sebuah program atau perencanaan pengajaran, akan tetapi sangat tergantung sekali dengan kemampuan guru dalam menerapkan berbagai keterampilan yang dimilikinya untuk dapat menciptakan situasi atau iklim belajar yang kondusif di kelas.

\section{Pelaksanaan}

Selesainya tahap persiapan tersebut maka langkah selanjutnya adalah bagaimana pelaksanaannya. Dalam pelaksanaan pembelajaran PAI di SMA Bukit Barisan Padang, guru memulai dengan pretest yang dilakukan untuk mengetahui kemampuan dan kesiapan siswa untuk menerima pelajaran dan juga untuk menentukan gaya mengajar.

Agar materi dapat terlaksana dengan baik dan lancar maka guru menggunakan berbagai keterampilan mengajar yang dimilikinya seperti halnya reinforcement skill baik dalam bentuk penguatan verbal maupun nonverbal.

Analisis penulis dari hasil pengamatan terhadap penerapan penguatan nonverbal yang dilakukan oleh guru di SMA Bukit Barisan Padang adalah sebagai berikut:

1). Dalam bentuk penguatan verbal, pada umumnya guru menerapkan dengan cara memberikan komentar yang berupa ungkapan kata-kata pujian, penghargaan, persetujuan, dukungan dan lain-lain. Seperti yang penulis dengar, misalnya:

1. Kata-kata seperti baik, bagus, bagus sekali, sangat tepat .

2. Kalimat, kamu mengerjakannya dengan baik sekali serta rapi.

3. Ayo kamu pasti bisa mengerjakan soal ini

4. Pendapat yang bagus!
Kalimat atau ungkapan kata-kata seperti ini sering sekali diterapkan guru dalam mengajar dalam rangka memberikan penguatan kepada siswa yang memang terpancing konsentrasinya untuk memberikan respon positif terhadap materi pelajaran yang diajarkan di kelas.

2). Bentuk penguatan nonverbal, umumnya guru dalam hal ini menggunakan bahasa tubuh atau bahasa isyarat, misalnya:

a). Penguatan berupa mimik dan gerakan badan

Guru menerapkan penguatan yang berupa mimik dan gerakan badan, seperti anggukan, senyuman, acungan jempol atau tepuk tangan, gelengan kepala, wajah cerah, serta sorot mata yang sejuk bersahabat dan biasanya disertai penguatan verbal, seperti guru menepuk-nepuk pundak siswa yang disertai ungkapan bapak bangga sama kamu.

Dalam hal ini, penulis melihat tidak selamanya penguatan jenis ini dilakukan guru bersamaan dengan penguatan verbal tanpa penguatan verbal pun penguatan ini tetap akan memberikan nilai penguatan kepada siswa.

b). Penguatan dengan cara mendekati

Penguatan ini caranya guru mendekati siswa dalam rangka memberikan perhatian dan kesenangannya terhadap pelajaran, tingkah laku, atau penampilan siswa. Seperti guru berdiri di samping siswa, berjalan menuju siswa, duduk dekat seorang atau sekelompok siswa, atau berjalan di sisi siswa. Penulis melihat penguatan seperti ini biasanya memperkuat penguatan verbal, hal ini terjadi karena diperkuatnya kehangatan dan keantusiasan oleh guru dengan mendatangi siswa tersebut dengan cara yang santun lagi bersahaja.

c). Penguatan dengan sentuhan

Memberikan penghargaan kepada siswa dapat dilakukan dengan sentuhan, guru dapat menyatakan persetujuan dan penghargan terhadap usaha dan penampilan siswa dengan cara menepuk-nepuk bahu atau pundak siswa, berjabat tangan, mengangkat tangan siswa yang menang dalam pertandingan. Hal yang harus diperhatikan yaitu penguatan ini harus disesuaikan dengan umur, jenis kelamin serta adat istiadat di tempat tersebut. Contohnya jika di suatu pesantren tidak mungkin untuk memberikan sentuhan kepada jenis kelamin yang 
berbeda karena dikhawatirkan mendatangkan fitnah bagi guru dan siswa yang bersangkutan.

Penerapannya pada SMA Bukit Barisan Padang penulis melihat bahwa penguatan dengan sentuhan ini hanya sekedarnya saja diberikan guru kepada siswa, seperti menjabat tangan siswa sebagai penghargaan terhadap usaha dan penampilannya atau cukup mengankat tangan siswa manakala menang dalam suatu ajang perlombaan atau pertandingan.

d). Penguatan dengan kegiatan yang menyenangkan siswa

Kegiatan yang menyenangkan siswa dapat bermakna menjadi suatu penguat manakala siswa yang menerimanya menyikapi sebagai sebuah kehormatan dan atau kepercayaan yang di berikan kepadanya. Dengan demikian, ia tidak dipandang sebagai sebuah beban baru bagi siswa melainkan sebagai sebuah perhatian yang diberikan kepadanya. Terhadap siswa yang memiliki prestasi di bidang musik diberi kepercayaan untuk memimpin paduan suara di sekolahnya, atau siswa yang memiliki karya ilmiah yang baik diberi kesempatan untuk memamerkan hasil karyanya di ruang guru.

Penguatan seperti ini telah dilakukan oleh beberapa guru terhadap siswa yang memiliki karya ilmiyah yang bagus, di mana guru memberikan waktu kepada siswa tersebut untuk mempresentasikannya di depan kelas dan di simak oleh siswa lainnya. Hal semacam ini dilakukan guru dalam rangka untuk menyenangkan atau memberikan rasa bangga kepada siswa tersebut.

e). Penguatan dengan simbol atau benda

Simbol tampaknya mempunyai arti penting di hadapan para siswa. Simbol dapat berupa bintang, lencana, piagam, tanda penghargaan. Benda bisa berupa alat-alat tulis, tas, bahkan baju seragam sekolah. Benda-benda tersebut tidak mesti mahal namun di usahakan memiliki arti simbolis yang dalam, bahkan komentar secara tertulis atas hasil pekerjaan siswa juga dapat berfungsi sebagai penguatan. Penguatan ini sebaliknya tidak terlampau sering digunakan, terutama yang berwujud benda, agar maknanya tidak hilang atau agar tidak menjadi kebiasaan bahwa siswa mengharapakan imbalan dari penampilannya.
Penerapannya pada SMA Bukit Barisan Padang penulis belum melihat hal seperti ini dilakukan oleh guru terhadap hasil kerja siswa yang baik sebagai penguatan. Mungkin saja penguatan dengan simbol atau benda ada dilakukan tapi tidak kelihatan karena bisa saja guru memberikannya dalam bentuk komentar positif secara tertulis atas hasil pekerjaan siswa tersebut.

f). Penguatan tidak penuh

Penguatan ini, siswa yang salah tidak langsung di salahkan secara kasar tetapi dengan memberikan penguatan tidak penuh, misalnya penguatan tak penuh seperti "yah, jawabanmu sudah baik tetapi masih perlu disempurnakan" "yang sudah kamu kerjakan sudah sesuai dengan caranya tetapi sebaiknya kamu lebih teliti terhadap nilai sin di kuadaran 3". Kemudian, diminta siswa lain untuk menyempurnakan atau menambahkan sehingga siswa tadi mengetahui bahwa jawabannya tidak seluruhnya benar, namun juga tidak salah. Demikian penulis memperhatikan beberapa orang guru melaksanakannya di kelas ketika mendapati siswa yang kurang sempurna mengerjakan tugas atau kurang lengkap memberikan komentar terhadap pertanyaan guru.

Beberapa hal tersebut di atas menurut E. Mulyasa. Dalam bukunya yang berjudul: Menjadi Guru Profesional (Menciptakan Pembelajaran Kreatif dan Menyenangkan). Memamng diakui bahwa penguatan dapat dilakukan secara verbal dan nonverbal, dengan prinsip kehangatan, keantusiasan, kebermaknaan dan menghindari penggunaan respon yang negatif, (Moh Uzer Usman, 2008: 80-83) demi terciptanya pembelajaran yang kreatif dan menyenangkan dalam proses pembelajaran.

Di samping itu, penulis juga melihat adanya motivasi yang dibangun oleh guru untuk memancing konsentarsi siswa dalam belajar. Peserta didik akan aktif dalam kegiatan belajarnya bila ada motivasi, baik itu motivasi ekstrinsik maupun instrinsik.

Selanjutnya ada beberapa hal yang dapat merangsang tumbuhnya motivasi belajar aktif pada diri siswa, antara lain : 
a). Penampilan guru yang hangat dan menumbuhkan partisipasi positif

Sikap guru tampil hangat, bersemangat, penuh percaya diri dan antusias, serta dimulai dan pola pandang bahwa peserta didik adalah manusia-manusia cerdas berpotensi, merupakan faktor penting yang akan meningkatkan partisipasi aktif peserta didik. Segala bentuk penampilan guru akan membias mewarnai sikap para peserta didiknya. Bila tampilan guru sudah tidak bersemangat maka jangan harap akan tumbuh sikap aktif pada diri peserta didik. Karena itu hendaknya seorang guru dapat selalu menunjukkan keseriusannya terhadap pelaksanaan proses, serta dapat meyakinkan bahwa materi pelajaran serta kegiatan yang dilakukan merupakan hal yang sangat penting bagi peserta didik, sehingga akan tumbuh minat yang kuat pada diri para peserta didik yang bersangkutan.

b). Peserta didik mengetahui maksud dan tujuan pembelajaran

Bila peserta didik telah mengetahui tujuan dari pembelajaran yang sedang mereka ikuti, maka mereka akan terdorong untuk melaksanakan kegiatan tersebut secara aktif. Oleh karena itu pada setiap awal kegiatan guru berkewajiban memberi penjelasan kepada peserta didik tentang apa dan untuk apa materi pelajaran itu harus mereka pelajari serta apa keuntungan yang akan mereka peroleh. Selain itu hendaknya guru tidak lupa untuk mengadakan kesepakatan bersama dengan para peserta didiknya mengenai tata tertib belajar yang berlaku agar kegiatan pembelajaran dapat berlangsung lebih efektif.

c). Tersedia fasilitas, sumber belajar, dan lingkungan yang mendukung

Bila di dalam kegiatan pembelajaran telah tersedia fasilitas dan sumber belajar yang "menarik" dan "cukup" untuk mendukung kelancaran kegiatan belajar mengajar maka hal itu juga akan menumbuhkan semangat belajar peserta didik. Begitu pula halnya dengan faktor situasi dan kondisi lingkungan yang juga penting untuk diperhatikan, jangan sampai faktor itu memperlunak semangat dan keaktifan peserta didik dalam mengikuti kegiatan belajar.

d). Adanya prinsip pengakuan penuh atas pribadi setiap peserta didik

Agar kesadaran akan potensi, eksistensi, dan percaya diri pada diri peserta didik dapat terus tumbuh, maka guru berkewajiban menjaga situasi interaksi agar dapat berlangsung dengan berlandaskan prinsip pengakuan atas pribadi setiap individu. Sehingga kemampuan individu, pendapat atau gagasan, maupun keberadaannya perlu diperhatikan dan dihargai. Dan yang penting lagi guru hendaknya rajin memberikan apresiasi atau pujian bagi para peserta didik, antara lain dengan mengumumkan hasil prestasi, mengajak peserta didik yang lain memberikan selamat atau tepuk tangan, memajang hasil karyanya di kelas atau bentuk penghargaan lainnya.

e). Adanya konsistensi dalam penerapan aturan atau perlakuan oleh guru di dalam proses belajar mengajar.

Perlu diingat bahwa bila terjadi kesalahan dalam hal perlakuan oleh guru di dalam pengelolaan kelas pada waktu yang lalu maka hal itu berpengaruh negatif terhadap kegiatan selanjutnya. Penerapan peraturan yang tidak konsisten, tidak adil, atau kesalahan perlakuan yang lain akan menimbulkan kekecewaan dari para peserta didik, dan hal ini akan berpengaruh terhadap tingkat keaktifan belajar peserta didik. Karena itu di dalam memberikan sanksi harus sesuai dengan ketentuannya, memberi nilai sesuai kriteria, dan memberi pujian tidak pilih kasih. 
f). Adanya pemberian "penguatan" dalam proses belajar-mengajar.

Penguatan adalah pemberian respon dalam interaksi belajar-mengajar baik berupa pujian maupun sanksi. Pemberian penguatan ini dimaksudkan untuk lebih meningkatkan keaktifan belajar dan mencegah berulangnya kesalahan dari peserta didik. Penguatan yang sifatnya positif dapat dilakukan dengan kata-kata; bagus! baik!, betul!, hebat! Namun semua itu tidak disajikan dengan cara berpura-pura tetapi harus tulus dari nurani guru. Dan sebagainya, atau dapat juga dengan gerak; acungan jempol, tepuk tangan, menepuk-nepuk bahu, menjabat tangan dan lain-lain. Ada pula dengan cara memberi hadiah seperti hadiah buku, benda kenangan atau diberi hadiah khusus berupa; boleh pulang duluan atau pemberian perlakuan menyenangkan lainnya.

g). Jenis kegiatan Pembelajaran menarik atau menyenangkan dan menantang

Agar peserta didik dapat tetap aktif dalam mengikuti kegiatan atau melaksanakan tugas pembelajaran perlu dipilih jenis kegiatan atau tugas yang sifatnya menarik atau menyenangkan bagi peserta didik di samping juga bersifat menantang. Pelaksanaan kegiatan hendaknya bervariasi, tidak selalu harus di dalam kelas, diberikan tugas yang dikerjakan di luar kelas seperti di perpustakaan, dan lain-lain. Penerapan model "belajar sambil bekerja" (learning by doing) sangat dianjurkan, di jenjang sekolah dasar antara lain dilakukan belajar sambil bernyanyi atau belajar sambil bermain. Untuk lebih mengaktifkan peserta didik secara merata dapat diterapkan pemberian tugas pembelajaran secara individu atau kelompok belajar (group learning) yang didukung adanya fasilitas/sumber belajar yang cukup. Sekiranya tersedia dianjurkan penggunaan media pembelajaran sehingga pelaksanaan pembelajaran dapat lebih efektif.

h). Penilaian hasil belajar dilakukan serius, obyektif, teliti dan terbuka

Penilaian hasil belajar yang tidak serius akan sangat mengecewakan peserta didik, dan hal itu akan memperlemah semangat belajar. Oleh karena itu, agar kegiatan penilaian ini dapat membangun semangat belajar para peserta didik maka hendaknya dilakukan serius, sesuai dengan ketentuannya, jangan sampai terjadi manipulasi, sehingga hasilnya dapat obyektif. Hasil penilaiannya diumumkan secara terbuka atau yang lebih baik dibuatkan daftar kemajuan hasil belajar yang ditempel di kelas. Dari daftar kemajuan belajar tersebut setiap peserta didik dapat melihat prestasi mereka masing-masing tahap per tahap.

Beberapa hal yang dapat merangsang tumbuhnya motivasi belajar aktif pada diri siswa di atas, sedikit banyaknya sudah dipraktekkan oleh guru hanya saja belum sepenuhnya sempurna. Hal ini dikarenakan keadaan sekolah sendiri yang belum siap secara utuh baik dari segi kebijakan, peraturan maupun kelengkapan bahan ajar sehingga mempengaruhi terhadap keseriusan kerja guru. Berdasarkan keterangan tersebut, dapat disimpulkan bahwa penerapan keterampilan penguatan (reinforcement skill) oleh guru dalam proses belajar mengajar bisa dikategorikan cukup baik sekalipun belum sepenuhnya. Namun secara umum penulis melihat bahwa penggunaan berbagai keterampilan penguatan sudah berusaha diterapkan oleh guru cukup bervariasi, walaupun masih ada beberapa guru yang terkesan dan masih monoton alias belum bisa menerapkannya secara keseluruhan.

Perlu disadari bahwa reinforcement skill bukan merupakan satu-satunya hal yang diperlukan untuk mendapatkan hasil yang optimal dari setiap kegiatan pembelajaran. Sebagaimana statemen orang Arab mengungkapkan "metode lebih penting dari 
materi" materi lebih penting dari metode" dan guru lebih penting dari metode". Hal ini menunjukkan bahwa guru, materi dan metode merupakan komponen yang sangat penting dalam sistem pembelajaran.

B. Kontribusi Reinforcement Skill terhadap Kreatifitas dan Peningkatan Tingkah Laku Produktif Siswa di SMA Bukit Barisan Padang

\section{Implikasi}

Berdasarkan pengamatan yang penulis lakukan jika pada suatu kelas manakala seorang guru memberikan pujian atau memberikan penghargaan dan persetujuan kepada siswa tertentu penulis lihat siswa tersebut lebih bersemangat lagi mengikuti proses pembelajaran.

Hal ini penulis buktikan lagi dengan cara melakukan observasi ke kelas lain dan memperhatikan beberapa siswa yang bisa menjawab pertanyaan yang dilontarkan oleh guru, dan setelah guru memberikan penguatan, siswa-siswa tersebut tampak lebih bersemangat, dan pada kesempatan berikutnya penulis lanjutkan observasi, ternyata siswa tersebut lebih bisa menjawab setiap yang ditanyakan guru karena telah belajar di rumah. Setelah penulis melakukan wawancara, siswa tersebut mengatakan bahwa dia sangat senang apabila usahanya yang maksimal dengan belajar lebih baik dan kreativitasnya dalam menyerap pelajaran dihargai oleh guru walau hanya sekedar pujian, karena bisa membuatnya lebih giat lagi belajar.

Lebih lanjut menurut pengamatan penulis, penguatan yang tepat yang diberikan oleh guru baik itu kepada siswa tertentu, sekelompok siswa atau satu lokal yang efektif meningkatkan kreatifitas siswa dalam belajar, di samping itu ketrampilan penguatan atau reinforcement juga mempunyai implikasi yang baik bagi siswa juga terhadap guru seperti yang disampaikan oleh seorang guru :
"Penguatan (reinforcement) memang sangat berguna merangsang anak-anak untuk lebih kreatif karena meraka akan saling berpacu belajar dengan giat, akan tetapi bagi kami (selaku guru) reinforcement juga mempunyai implikasi yang baik karena dengan penguatan yang diberikan pelajaran lebih bisa diserap dengan baik, dan bagi guru tiada kebanggaan yang lebih besar selain bila anak bisa mengerti dengan apa yang diajarkan." (Wawancara, Marini :13 April 2009).

Kemudian dalam hal ini penulis melihat ketrampilan guru dalam menerapkan reinforcement atau ketrampilan penguatan khususnya, juga mempunyai implikasi terhadap kebiasaan siswa yang terkadang mengidolakan seorang guru. Hal ini terlihat setelah penulis melakukan wawancara dengan beberapa orang siswa, dan mereka mengatakan:

"Kami memang memiliki guru yang sangat kami sukai karena pandai mengajar, dan sangat menghargai apa yang kami lakukan (memberi penguatan) sehingga kami selalu gembira bila belajar dengan guru tersebut."

(Wawancara: Nobel Afred, Dwi Putra Haryo, Regi Ananda, Auliya Suzeno dan Febi Sastra Negara: 13 April 2009).

Mereka juga mengatakan:

"Memang diakui kami sangat jemu belajar dengan beberapa orang guru, hal ini disebabkan cara mengajar yang kurang bervariasi dan belajar dengan situasi yang menjemukan dan apabila mereka ditanya serta bisa menjawab, guru tersebut hanya diam dalam arti kata kurang respon melanjutkan pelajaran seakan-akan tidak terjadi apa-apa , akibatnya siswa tersebut merasa bingung apakah jawabannya betul atau salah" (Wawancara: Nobel Afred dan Regi Ananda: 13 April 2009).

Dari keterangan di atas jelaslah bahwa ketrampilan penguatan sangat efektif menunjang kreatifitas dan tingkah laku produktif siswa dalam proses pembelajaran. Tanpa adanya 
penerapan ketrampilan tentunya kejemuan atau kebosanan akan cepat dan mudah melanda semangat siswa untuk mengikuti proses pembelajaran di kelas. Apalagi kalau guru merasa berat hati atau enggan untuk memberikan pujian atau penghargaan kepada siswa tentu akan menjadikan kondisi belajar menjadi kaku alias tidak hidup dan bergairah.

Pemberian penguatan oleh guru di SMA Bukit Barisan Padang menurut analisis penulis, sangat mempunyai pengaruh positif terhadap proses pembelajaran terutama dalam pembelajaran PAI, reinforcement skill yang diterapkan oleh guru dapat meningkatkan perhatian siswa terhadap agamanya. Hal ini dapat dibuktikan dengan adanya sertifikat kegiatan keagamaan siswa di luar sekolah yang diberikan oleh pengurus masjid/ mushalla dimana tempat siswa berdomisili. Lebih lagi kegiatan rutin keagamaan pada setiap bulan puasa atau bulan suci Ramadhan.

Dalam hal pembelajaran penulis juga melihat bahwa reinforcement juga dapat memudahkan dan melancarkan proses pembelajaran, siswa mampu membangkitkan bahkan mempertahankan motivasi yang telah dibangun oleh guru yang sebelumnya kurang bernafsu untuk mengikuti pembelajaran. Seperti yang dikemukakan oleh Hasibuan pada bab dua sebelumnya, bahwa keterampilan mengajar guru akan dapat mengontrol sikap yang akan mengganggu ke arah tingkah laku yang produktif dan mengarahkan pada cara berfikir yang baik dan elegan.

Hal senada juga diungkapkan oleh Soetomo, bahwa dengan adanya pemberian penguatan oleh guru itu akan dapat meningkatkan perhatian dan motivasi siswa terhadap materi pelajaran. Kemudian dapat mendorongnya untuk berbuat baik yang lebih produktif. Lebih dari itu penguatan dapat pula menumbuhkan rasa percaya diri siswa dan meningkatkan cara belajarnya dengan aktif. Tentunya semua hal tersebut tidak lepas dari beberapa faktor sebagai pendorong atau penunjang terlaksananya reinforcement skill oleh guru. Begitu pun dengan faktor penghambatnya yang memungkinkan terjadinya kendala dalam penerapannya di kelas.
Berdasarkan analisis penulis ternyata terdapat beberapa faktor yang menjadi penunjang dan penghambat dalam penerapan reinforcement skill dalam proses pembelajaran. Adapun yang menjadi faktor pendunkung dan penghambat itu antara lain :

\section{Faktor Pendukung}

Faktor ini adalah merupakan hal-hal penunjang dalam penerapan reinforcement skill antara lain adalah :

a. Adanya kemamuan atau kesadaran siswa untuk belajar, siswa sangat tremotivasi terhadap pengembangan serta peningkatan kualitas keagamaan sehingga mempermudah kerja guru

b. SDM tenaga pengajar yang berkualitas dan professional sangat mendukung terhadap penerapan reinforcement skill

c. Kreatifitas guru dalam mengembangkan materi secara mandiri ataupun mengadopsi dari berbagai pengalaman mengajar atau juga dari sumber buku lainnya

d. Adanya sarana dan prasarana yang dianggap cukup dalam pelaksanaan pembelajaran seperti rencana pengajaran yang lengkap

e. Persiapan yang matang yang diagendakan oleh guru sehingga dapat memperlancar proses pembelajaran

Kamudian berdasarkan analisa penulis dan hasil penelitian mengenai faktor pendukung penerapan reinforcement skill itu di antaranya:

Pertama, jika dalam tahap awal pembelajaran dalam arti kata saat guru bisa memancing konsentrasi siswa dan membuka pelajaran dengan mengalihkan perhatian siswa dari apa saja yang bisa mengganggu konsentrasinya. Maka dalam menerapkan ketrampilan penguatan nantinya guru akan memberikan dengan antusias dan hangat karena guru merasa senang dengan kelasnya yang tenang.

Kedua, latar belakang pendidikan yang umunya tamatan fakultas pendidikan (tarbiyah) dan ilmu kependidikan juga ikut mendukung peranan guru menerapkan ketrampilan penguatan, di samping itu hal-hal lain yang mendukung adalah ketrampilan guru dalam menerapkan berbagai ketrampilan mengajar, sebagai contoh apabila dalam menerapkan ketrampilan menjelaskan dapat dilakukan dengan baik maka 
secara otomatis siswa bisa menyerap pelajaran dengan baik sehingga sewaktu guru bertanya lalu dijawab dengan baik otomatis guru bisa menerapkan ketrampilan penguatan dengan segera dan terpadu, dalam hal tersebut ada keseimbangan antara kesuksesan penerapan ketrampilan penguatan dengan penerapan ketrampilan mengajar yang lain.

Ketiga, suasana belajar yang dilaksanakan satu gelombang (pagi saja) sehingga konsentrasi siswa dalam mengikuti pelajaran lebih baik dibanding sore hari, begitu juga bagi guru, berdasarkan wawancara penulis dengan salah seorang guru yang menyatakan bahwa :

"Suasana pembelajaran yang pagi saja juga ikut punya andil dalam penyerapan siswa terhadap topik pelajaran, dengan sendirinya juga bisa menciptakan suasana yang penuh semangat pada proses pembelajaran." (Wawancara, Diah: 25 April 2009).

Ketiga hal tersebut di atas, menurut penulis tidak kalah pentingnya dengan faktorfaktor pendukung yang disebutkan sebelumnya. Karena untuk menciptakan pembelajaran yang aktif, inovatif, kreatif, efektif dan menyenangkan (PAIKEM) itu tidak terlepas dari sejauhmana kesiapan siswa dan guru untuk menerima dan memberi materi pembelajaran.

2. Faktor Penghambat

Faktor ini adalah merupakan kendala-kendala dalam penerapan reinforcement skill antara lain adalah :

a. Terkadang guru kurang matang dalam memepersipkan perangkat mengajar atau pembelajaran sehingga menghambat dalam pelaksanaannya

b. Kurangnya pengetahuan sebagian guru tentang siswa-siswa yang mereka hadapai seperti tingkat kecerdasan siswa, bakat dan minat

c. Terbatasnya bahan atau sumber belajar yang tersedia di sekolah maupun yang dimiliki oleh guru

d. Minimnya media pembelajaran yang tersedia dalam menunjang pembelajaran

e. Terbatasnya dana dan anggaran dalam mencukupi sarana dan prasarana belajar yang memadai
Sedangkan faktor penghambat lainnya setelah penulis melakukan pengamatan adalah:

Pertama, kurang piawainya guru melakukan pengelolaan kelas, bahkan ada sebagian guru dalam menjelaskan pelajaran menggunakan metode yang tidak beragam sehingga menyebabkan siswa menjadi bosan dan sulit menyerap apa yang disampaikan guru. Akibatnya bila guru bertanya tentang pelajaran yang diberikan, siswa kurang bahkan tidak mampu untuk menjawab. Kedua, penulis melihat ada faktor lain seperti, ada sebagian siswa yang merasa cemburu kepada temannya bila dipuji dan menurut pengamatan penulis hal ini disebabkan guru hanya memperhatikan segelintir siswa (siswa yang pintar), akibatnya siswa yang lain merasa tidak diperhatikan akibatnya mereka kurang bersemangat untuk belajar. Ketiga, lebih lanjut menurut pengamatan penulis dalam penerapan ketrampilan penguatan sebenarnya kendala terbesar disebabkan oleh penggunaan penguatan yang itu-itu saja, seperti terlalu seringnya menggunakan penguatan verbal yaitu dengan kata-kata yang bagus. Hal inilah yang secara teori bisa menyebabkan kejemuan siswa, sehingga siswa tidak termotivasi untuk berbuat lebih baik lagi karena sudah biasa mendengar kata-kata bagus. Keempat, karena masih adanya guru yang kurang menguasai bahan dalam mengajar, buktinya penulis melihat guru masih sering melihat-lihat buku pada waktu sedang menerangkan pelajaran. Padahal guru harus tahu sejauh mana bahan yang telah dijelaskan dapat dimengerti oleh siswa, agar dapat melanjutkan pelajaran dengan materi berikutnya. Jika siswa kurang mengerti, guru haurs mengulangi lagi penjelasannya.

\section{SIMPULAN}

Berdasarkan uraian tersebut di atas maka dapat disimpulkan gambaran penerapan reinforcement skill dalam pembelajaran PAI di SMA Bukit Barisan Padang sebagai berikut :

1. Penerapan reinforcement skill dalam pembelajaran PAI di SMA Bukit Barisan Padang secara umum telah diterapkan oleh masing-masing guru khususnya guru PAI. Hal ini disebabkan adanya kreativitas guru dalam mengembangkan materi atau bahan ajar secara mandiri, latar belakang 
pendidikan dan persiapan maksimal oleh guru pada saat akan mengajar, keluwesan menerapkan segenap komponen keterampilan mengajar dan partisipasi aktif siswa mengikuti pembelajaran atau juga meniru dari pengalaman rekan-rekan sesama guru dalam mengajar. Semuanya turut andil memberikan motivasi atau dorongan dalam penerapannya.

2. Sedangkan dalam penggunaannya masih terkesan kurang variatif atau beragam, dan masih belum sepenuhnya optimal. Hal ini disebabkan terbatasnya sarana dan prasarana sebagai penunjang dalam pembelajaran yang mengakibatkan lambannya kegiatan pembelajaran itu sendiri. Kemudian dalam menjelaskan masih ada beberapa guru menggunakan metode yang sifatnya monoton (itu-itu saja), dalam arti kata kemampuan profesional guru secara praktik masih minim, kurang adilnya guru memberikan penghargaan atau perhatian terhadap siswa dan juga disebabkan kurangnya kreativitas siswa itu sendiri.

3. Dalam memberikan penguatan, guru dapat memberikan penguatan dalam bentuk penguatan verbal dan nonverbal. Pembelajaran yang efektif akan dapat menghindari rasa bosan dan jenuh siswa, sehingga dengan adanya pemebelajaran yang efektif, kreatif dan meneyenangkan itu maka tujuan pembelajaran akan mudah tercapai. Selain penguatan tersebut guru juga bisa menyelingi pembelajaran itu dengan sedikit humorsence atau carita lucu sekedar untuk menormalkan kembali kegiatan pembelajaran.

4. Kontribusi reinforcement skill terhadap kreativitas dan peningkatan tingkah laku produktif siswa yaitu; pertama, dapat meningkatkan perhatian siswa terhadap pelajaran. Ada kalanya siswa mengalami sedikit penurunan perhatian terhadap pelajaran yang bisa saja diakibatkan oleh waktu dalam proses belajar yang berakibat pada kebosanan. Dengan keterampilan ini maka kebosanan tersebut akan hilang dikarenakan meningkatnya perhatian yang diberikan siswa terhadap belajar, kedua, merangsang dan meningkatkan motivasi belajar, ketiga, meningkatkan kegiatan belajar dan membina tingkah laku siswa yang produktif.

Ketika motivasi dan perhatian dalam belajar mengalami peningkatkan maka secara langsung kegiatan belajar yang terjadi akan meningkat, keempat, keterampilan mengajar juga akan memudahkan siswa belajar dan kelima, penguatan juga sangat efektif menunjang kreatifitas dan tingkah laku produktif siswa dalam belajar, sehingga menjadikan siswa lebih bersemangat dan termotivasi dalam mengikuti pembelajaran. Manfaat penguatan bagi siswa untuk meningkatnya perhatian dalam belajar, membangkitkan dan memelihara perilaku, menumbuhkan rasa percaya diri, dan memelihara iklim belajar yang kondusif.

\section{DAFTAR RUJUKAN}

Arikunto, Suharsimi, (1991). Prosedur Penelitian, Jakarta: Rineka Cipta

Darwis, Djamaluddin. (1990). Strategi Belajar Mengajar dalam Chabib Thaha (ed)Proses Belajar Mengajar PAI di Sekolah, Eksistensi dan Proses Belajar Mengajar PAI, Yogyakarta: Pustaka Pelajar dan Fakultas Tarbiyah IAIN Walisongo Semarang.

E. Mulyasa, (2008). Menjadi Guru Profesional :Menciptakan Pembelajaran yang Kreatif dan Menyenangkan, Bandung: PT Remaja Rosdakarya.

S. Nasution. (1982). Metode Resaerach. Bandung: Jenmars

Suseno, Gilarso. (1986). Program Pengalaman lapangan I, Jakarta: Adi Ofset

Tim Didaktik Metodik Kurikulum IKIP Surabaya. (1993). Pengantar Didaktik Metodik Kurikulum PBM. Jakarta: Surabaya

Usman, Moh. Uzer. (2008). Menjadi Guru Profesional. Bandung: PT Remaja Rosdakarya 